ISSN 0258-7122

Bangladesh J. Agril. Res. 39(3): 505-513, September 2014

\title{
EFFECT OF HYDROPRIMING AND SOIL MOISTURE REGIMES ON YIELD AND YIELD COMPONENTS OF MAIZE (Zea mays L.)
}

\author{
K. U. AHAMMAD ${ }^{1}$, M. M. RAHMAN ${ }^{2}$, M. A. M. MOLla ${ }^{3}$ AND M. G. AZAM ${ }^{4}$
}

\begin{abstract}
The experiment was conducted at the research field of Regional Agricultural Research Station, Jessore during two consecutive rabi seasons of 2008-2009 and 2009-2010 to find out the effect of hydropriming on the performance of maize seeds under variable soil moisture regimes. The treatments of the experiment were two priming methods viz., i) Hydropriming, ii) Non-priming and four moisture regimes viz., i) Wet condition, ii) Field capacity, iii) $75 \%$ of field capacity, and iv) $50 \%$ of field capacity. Results showed that yield and yield contributing characters (plant population $/ \mathrm{m}^{2}$, number of cobs $/ \mathrm{m}^{2}$, length of $\mathrm{cob}$, diameter of cob, 100-grain weight) were influenced significantly by hydropriming. Yield and yield contributing characters were highest when hydroprimed seeds were sown at field capacity whereas it was the lowest at $75 \%$ of field capacity from non- primed seeds. Days to tasseling, days to silking, and days to maturity were reduced when hydroprimed seeds were sown at field capacity. At $50 \%$ of field capacity, no germination was occurred.
\end{abstract}

Keywords: Hydropriming, maize, soil moisture, yield.

\section{introduction}

Maize (Zea mays L.) is one of the most important food grains of the world. In Bangladesh, maize ranks third in respect of total acreage after rice and wheat but ranks first in respect of average yield which was $5.30 \mathrm{t} / \mathrm{ha}$ (BBS, 2010). Maize is the most popular and palatable feed for all kinds of livestock and poultry birds all over the world (Hossain and Shahjahan, 2007). Good seedling establishment is an important prerequisite for successful crop production (Harris et al., 1999) and this is particularly true for crops, such as maize which do not have the capacity to adjust to sub-optimal stand by tillering (Finch Savage et al., 2004). From seed sowing to seedling establishment, seeds are exposed to a wide range of environmental factors that adversely affect germination performance. Constraints to good establishment of crops include low seed quality, lack of soil moisture, temperature extremities, soil salinity, poor seed bed preparation, weed competition, extreme disease pressure, etc. (Townend et al., 1996). Water stress is one of the major environmental constraints that limit crop productivity worldwide (Araus et al., 2002). It affects every aspect of plant growth (Rahman et al., 2004). Water stress has been found to reduce leaf area, photosynthesis, leaf

${ }^{1}$ Senior Scientific Officer, RARS, Bangladesh Agricultural Research Institute (BARI), Jessore, ${ }^{2}$ Professor, Department of Agronomy, Bangladesh Agricultural University (BAU), Mymansingh, ${ }^{3}$ Assistant Professor, Department of Agriculture, Kazi Azimuddin College, Gazipur, ${ }^{4}$ Scientific Officer, RARS, BARI, Jessore, Bangladesh. 
chlorophyll contents and consequently grain yield (Jun-Chen and Dai-Junying 1996). When seeds are sown, they have to absorb water from the soil which takes a long time before they germinate. If this time could be reduced by soaking the seeds before they are sown, germination happens more quickly resulting in a healthier crop. Seed priming can be a simple solution towards expected stand establishment (Harris et al., 2001). Seed priming is a process in which seeds are imbibed in water or osmotic solutions followed by drying before radical emergence (McDonald, 2000). Heydecker et al. (1973) defined osmotic seed priming as a pre-sowing treatment in an osmotic solution that allows seeds to imbibe water to proceed to the first stage of germination but prevent radicle protrusion through the seed coat. Harris et al. (1999) promoted a low cost, low risk technology called 'on-farm seed priming' that would be appropriate for all farmers, irrespective of their socio-economic status. On-farm seed priming involves soaking the seed in water, surface drying and sowing the same day. Hydropriming is being used to reduce the germination time to get synchronized germination, improve germination rate and better seedling in many crops, such as maize, soybean, wheat, lentil, chickpea, mungbean, cowpea, etc. (Singh, 1995). Maize is one of the important cereal crops of Bangladesh which can be produced successfully by priming seed at low moisture content of soil after harvesting transplant aman rice. Although quite a good number of works have been done on seed priming of maize in abroad but under Bangladesh condition, such works are a few. So, it is necessary to study the effects of seed priming in plant stand establishment and yield performance of maize. Therefore, the present study was undertaken to find out the effect of hydropriming on the performance of maize under variable soil moisture regimes at field condition.

\section{Materials and Method}

The experiment was conducted at the research field of Regional Agricultural Research Station, Jessore during two consecutive rabi seasons of 2008-09 and 2009-10. The experimental site belongs to the High Ganges River Floodplain soil. The soil is characterized by sandy loam to silty clay loam with $\mathrm{pH}$ value of 7.0-8.0. Organic matter, total $\mathrm{N}$, and $\mathrm{K}$ of the soil were $1.68 \%, 0.087 \%$, and $0.20 \mathrm{meq} / 100 \mathrm{~g}$ soil, respectively, and P, S, Zn, and B were 5.09, 20.20, 2.80, and $0.32 \mu \mathrm{g} / \mathrm{g}$ soil, respectively. The maximum and minimum average temperatures were 35 and $16{ }^{\circ} \mathrm{C}$ in the month of April and December, respectively, during 2008-09 to 2009-10. The total rainfalls were 1222.60 and $827.70 \mathrm{~mm}$ in $2008-09$ and 2009-10, respectively. There was no rainfall in the month of November to January during 2008-09 to 2009-10. Monthly average relative humidity ranged from 88.62 to $95.87 \%$ in $2008-09$ and 90.27 to $95.63 \%$ in $2009-10$. The experiment includes two priming methods viz., i) Hydropriming, ii) Nonpriming, and four moisture regimes viz., i) wet condition, ii) field capacity, iii) $75 \%$ of field capacity, and iv) $50 \%$ of field capacity. The experiment was laid out in a split plot design with four replications. Moisture regime was assigned as 
main plot and priming methods as sub-plot. Maize (var. BARI Hybrid Maize-5) seeds were taken in plastic bowls and submerged with distilled water for 18 hours. Then seeds were washed under tap water for several times and surface dried for two hours under shade. The field capacity of the experimental field was determined by field method (Misra and Ahmed, 1993). Moisture content of the soil at field capacity was $26 \%$. Therefore, the field capacity, $75 \%$ of FC and $50 \%$ of FC were created in different plots by adding water using the following formula (Michael, 1978):

Volume of water $($ Litre $)=\frac{\text { Desirable soil moisture\% initial soil moisture\% }}{100} \times$ Bulk density $\times$ Depth of soil $(\mathrm{cm}) \times$ Area $\left(\mathrm{cm}^{2}\right)$.

Wet condition was created by flood irrigation. At wet condition, soil become over saturated and the moisture content of soil was $30 \%$. Seeds were sown in well prepared plots at $2 \mathrm{~cm}$ depth in soil on 25 November in 2008 and 27 November in 2009 maintaining $75 \mathrm{~cm} \times 20 \mathrm{~cm}$ spacing. Fertilizers were applied at the rate of 230-48-90-43-3.5-1 kg/ha in the form of N-P-K-S-Zn, and B (BARI, 2006). One-third of urea and all other fertilizers were applied as basal during final land preparation. The rest amount of urea was applied in two splits at 30 and 50 days after sowing (DAS) (BARI, 2004). Two hand weedings were done at 20 and 40 days after sowing (DAS) for minimizing weed competition. Earthing-up was done at 50 DAS after second irrigation. First irrigation was applied at 30 DAS and other three irrigations were given at 50, 75, and 100 DAS. Maize was harvested from the central area of $8.1 \mathrm{~m}^{2}$ of each plot $(3.75 \mathrm{~m} \times 4 \mathrm{~m})$ excluding border lines for measuring yield contributing characters and yield. Harvested cobs were husked and sun dried. Then these were shelled by electric power driven corn sheller followed by cleaning and winnowing. Data on plant population $/ \mathrm{m}^{2}$, days to tasseling, days to silking, days to maturity, number of $\mathrm{cobs} / \mathrm{m}^{2}$, length of cob, diameter of cob, 100-grain weight, yield/ha, stover yield, and harvest index were recorded.

All the data of two years were pooled and subjected to statistical analysis using ANOVA technique through computer based statistical package programme MSTATC (Gomez and Gomez, 1984). Mean comparison was done by Duncun's Multiple Range Test (DMRT) at 5\% level.

\section{Results}

\section{Effect of priming}

Plant population $/ \mathrm{m}^{2}$, days to tasseling, days to silking and days to maturity varied significantly due to seed priming (Table 1). Hydroprimed seeds exhibited higher plant population $/ \mathrm{m}^{2}$ (5.23) than that of non-primed seeds (4.72). Lower days to tasseling (102 day), days to silking (105 day), and days to maturity (141 day) were obtained from hydroprimed seeds whereas the corresponding higher values were 
106, 109, and 145 days, respectively, from non-primed seeds. Number of cobs $/ \mathrm{m}^{2}$, cob length, cob diameter, grains/cob, 100-grain weight, grain yield, stover yield, and harvest index of maize were influenced significantly due to seed priming (Table 2). Higher cob number $/ \mathrm{m}^{2}(5.97)$, cob length $(18.89 \mathrm{~cm})$, cob diameter $(4.50 \mathrm{~cm})$, grains/cob (581.02), 100-grain weight (31.90 g), grain yield (10.84 t/ha), stover yield $(11.68 \mathrm{t} / \mathrm{ha})$, and harvest index $(48.13 \%)$ were found from hydroprimed seeds and the corresponding lower values were $5.31,18.30 \mathrm{~cm}, 4.13 \mathrm{~cm}, 515.32,31.07 \mathrm{~g}, 9.80$ t/ha, $11.02 \mathrm{t} / \mathrm{ha}$ and $47.05 \%$, respectively, from non-primed seeds.

\section{Effect of soil moisture regimes}

Plant population $/ \mathrm{m}^{2}$, days to tasseling, days to silking, and days to maturity varied significantly due to soil moisture (Table 1). The highest plant population $/ \mathrm{m}^{2}$ (5.28) was obtained from seeds sown at field capacity followed by wet condition (5.05) and the lowest (4.60) at $75 \%$ of field capacity. The minimum number of days to tasseling (103 day), days to silking (106 day), and days to maturity (142 day) were obtained at field capacity followed by wet condition and the corresponding highest values were 105,107 , and 144 days, respectively, at $75 \%$ of field capacity. Number of cobs $/ \mathrm{m}^{2}$, cob length, cob diameter, grains/cob, 100-grain weight, grain yield, stover yield, and harvest index of maize were influenced significantly due to soil moisture (Table 2). The highest number of cobs $/ \mathrm{m}^{2}(5.92)$, cob length $(18.89 \mathrm{~cm})$, cob diameter $(4.44 \mathrm{~cm})$, grains/cob $(568.60), 100$-grain weight $(31.75 \mathrm{~g})$, grain yield $(10.74 \mathrm{t} / \mathrm{ha})$, stover yield $(11.64 \mathrm{t} / \mathrm{ha})$, and harvest index $(47.97 \%)$ were obtained at field capacity followed by wet condition and the corresponding lowest values were $5.47,18.37 \mathrm{~cm}, 4.18 \mathrm{~cm}, 527.16,31.17 \mathrm{~g}, 9.80 \mathrm{t} / \mathrm{ha}, 11.06 \mathrm{t} / \mathrm{ha}$, and 46.96 at $75 \%$ of field capacity. All parameters showed zero value at $50 \%$ of field capacity for no germination occurred.

Table 1. Effect of seed priming and moisture regimes on the yield contributing characters of maize (pooled data of 2008-09 and 2009-10).

\begin{tabular}{lcccc}
\hline \multicolumn{1}{c}{ Treatments } & $\begin{array}{c}\text { Plant population } \\
\mathrm{m}^{-2}(\mathrm{no})\end{array}$ & $\begin{array}{c}\text { Days to } \\
\text { tasseling }\end{array}$ & $\begin{array}{c}\text { Days to } \\
\text { silking }\end{array}$ & $\begin{array}{c}\text { Days to } \\
\text { maturity }\end{array}$ \\
\hline Seed priming & \multicolumn{5}{c}{} \\
\hline Hydropriming & $5.23 \mathrm{a}$ & $102 \mathrm{a}$ & $105 \mathrm{a}$ & $141 \mathrm{a}$ \\
Non priming & $4.72 \mathrm{~b}$ & $106 \mathrm{~b}$ & $109 \mathrm{~b}$ & $145 \mathrm{~b}$ \\
\hline $\mathrm{S}_{\mathrm{x}}^{-}$ & 0.017 & 0.218 & 0.167 & 0.136 \\
\hline Moisture regimes & \multicolumn{5}{c}{} \\
\hline Wet condition & $5.05 \mathrm{~b}$ & $104 \mathrm{~b}$ & $107 \mathrm{~b}$ & $143 \mathrm{~b}$ \\
Field capacity & $5.28 \mathrm{a}$ & $103 \mathrm{c}$ & $106 \mathrm{c}$ & $142 \mathrm{~b}$ \\
$75 \%$ of FC & $4.60 \mathrm{c}$ & $105 \mathrm{a}$ & $108 \mathrm{a}$ & $144 \mathrm{a}$ \\
$50 \%$ of FC & - & - & - & - \\
\hline $\mathrm{S}_{\mathrm{x}}^{-}$ & 0.025 & 0.118 & 0.144 & 0.363 \\
$\mathrm{CV}(\%)$ & 1.15 & 0.73 & 0.54 & 0.33 \\
\hline
\end{tabular}

Figures with similar letter(s) or without letter in a column do not differ significantly whereas figures with dissimilar letter(s) differ significantly at 0.05 level of probability as per DMRT, - = No germination 
Table 2. Effect of seed priming and moisture regimes on the yield contributing characters and yield of maize (pooled data of 2008-09 and 2009-10).

\begin{tabular}{|c|c|c|c|c|c|c|c|c|}
\hline \multirow[b]{2}{*}{ Treatments } & \multirow{2}{*}{$\begin{array}{c}\text { Cobs/ } \\
\mathrm{m}^{2} \\
\text { (no.) }\end{array}$} & \multicolumn{2}{|c|}{ Cob size $(\mathrm{cm})$} & \multirow{2}{*}{$\begin{array}{c}\text { Grains/ } \\
\text { cob } \\
\text { (no) }\end{array}$} & \multirow{2}{*}{$\begin{array}{l}100- \\
\text { grain } \\
\mathrm{wt}(\mathrm{g})\end{array}$} & \multirow{2}{*}{$\begin{array}{l}\text { Grain } \\
\text { yield } \\
\text { (t/ha) }\end{array}$} & \multirow{2}{*}{$\begin{array}{c}\text { Stover } \\
\text { yield } \\
(\mathrm{t} / \mathrm{ha})\end{array}$} & \multirow{2}{*}{$\begin{array}{c}\text { Harvest } \\
\text { index } \\
(\%)\end{array}$} \\
\hline & & Length & Diameter & & & & & \\
\hline \multicolumn{9}{|l|}{ Seed priming } \\
\hline Hydropriming & $5.97 \mathrm{a}$ & $18.89 \mathrm{a}$ & $4.50 \mathrm{a}$ & $581.02 \mathrm{a}$ & $31.90 \mathrm{a}$ & $10.84 \mathrm{a}$ & $11.68 \mathrm{a}$ & $48.13 \mathrm{a}$ \\
\hline Non-priming & $5.31 \mathrm{~b}$ & $18.30 \mathrm{~b}$ & $4.13 \mathrm{~b}$ & $515.32 \mathrm{~b}$ & $31.07 \mathrm{~b}$ & $9.80 \mathrm{~b}$ & $11.02 \mathrm{~b}$ & $47.05 \mathrm{~b}$ \\
\hline $\mathrm{S}_{\mathrm{x}}^{-}$ & 0.045 & 0.084 & 0.026 & 1.912 & 0.049 & 0.042 & 0.041 & 0.071 \\
\hline \multicolumn{9}{|c|}{ Moisture regimes } \\
\hline Wet condition & $5.53 \mathrm{~b}$ & $18.52 \mathrm{~b}$ & $4.34 \mathrm{~b}$ & $548.74 \mathrm{~b}$ & $31.53 \mathrm{a}$ & $10.41 \mathrm{~b}$ & $11.34 \mathrm{~b}$ & $47.84 \mathrm{a}$ \\
\hline Field capacity & $5.92 \mathrm{a}$ & $18.89 \mathrm{a}$ & $4.44 \mathrm{a}$ & $568.60 \mathrm{a}$ & $31.75 \mathrm{a}$ & $10.74 \mathrm{a}$ & $11.64 \mathrm{a}$ & $47.97 \mathrm{a}$ \\
\hline $75 \%$ of $\mathrm{FC}$ & $5.47 \mathrm{~b}$ & $18.37 \mathrm{~b}$ & $4.18 \mathrm{c}$ & $527.16 \mathrm{c}$ & $31.17 \mathrm{~b}$ & $9.80 \mathrm{c}$ & $11.06 \mathrm{c}$ & $46.96 \mathrm{~b}$ \\
\hline $50 \%$ of FC & - & - & - & - & - & - & - & - \\
\hline $\mathrm{S}_{\mathrm{x}}^{-}$ & 0.057 & 0.096 & 0.025 & 2.276 & 0.068 & 0.080 & 0.079 & 0.092 \\
\hline $\mathrm{CV}(\%)$ & 2.73 & 1.57 & 2.08 & 1.21 & 0.53 & 1.42 & 1.26 & 0.52 \\
\hline
\end{tabular}

Figures with similar letter(s) or without letter in a column do not differ significantly whereas figures with dissimilar letter(s) differ significantly at 0.05 level of probability as per DMRT, - = No germination

\section{Interaction effect of priming and soil moisture regimes}

Plant population $/ \mathrm{m}^{2}$, number of cobs $/ \mathrm{m}^{2}$, cob diameter, grains/cob, 100-grain weight, grain yield of maize were influenced significantly due to interaction of seed priming and soil moisture (Table 3). The highest plant population $/ \mathrm{m}^{2}(5.54)$ was obtained at field capacity with hydroprimed seeds and the lowest (4.29) from non-primed seeds sown at $75 \%$ of field capacity. Plant population at field capacity with hydroprimed seeds was 10 and $29 \%$ higher than that of non-primed seeds sown at field capacity and $75 \%$ of field capacity, respectively. The highest number of cobs $/ \mathrm{m}^{2}$ (6.34), cob diameter $(4.63 \mathrm{~cm})$, number of grains/cob (606.28), 100grain weight $(32.24 \mathrm{~g})$ occurred at field capacity with hydroprimed seeds and these were lowest with non-primed seeds at $75 \%$ of field capacity. Grain yield of maize was affected significantly by the interaction effect of seed priming and soil moisture (Table 3$)$. The highest grain yield (11.21 t/ha) was obtained from sowing at field capacity with hydroprimed seeds and the lowest $(9.22 \mathrm{t} / \mathrm{ha})$ from nonprimed seeds sown at $75 \%$ of field capacity. Hydroprimed seeds sown at field capacity showed 9 and 22\% higher grain yield than the non- primed seeds sown at field capacity and at $75 \%$ of field capacity respectively. Cob length, stover yield, and harvest index of maize showed insignificant variation due to interaction of seed priming and soil moisture (Table 3). However, the highest cob length $(19.15 \mathrm{~cm})$, stover yield (11.87 t/ha), and harvest index $(48.56 \%)$ were observed at field capacity with hydroprimed seeds and the lowest of those were with non-primed seeds sown at $75 \%$ of field capacity. 
Table 3. Interaction effect of seed priming and moisture regimes on the yield contributing characters and yield of maize (pooled data of 2008-09 and 2009-10).

\begin{tabular}{|c|c|c|c|c|c|c|c|c|c|}
\hline \multirow{2}{*}{$\begin{array}{c}\text { Interaction of } \\
\text { seed priming and } \\
\text { moisture regimes }\end{array}$} & \multirow{2}{*}{$\begin{array}{c}\text { Plant } \\
\text { population/ } \\
\mathrm{m}^{2}(\mathrm{no})\end{array}$} & \multirow{2}{*}{$\begin{array}{c}\text { Cobs } / \mathrm{m}^{2} \\
\text { (no.) }\end{array}$} & \multicolumn{2}{|c|}{ Cob size $(\mathrm{cm})$} & \multirow{2}{*}{$\begin{array}{c}\text { Grains/ } \\
\text { cob } \\
\text { (no.) }\end{array}$} & \multirow{2}{*}{$\begin{array}{c}\text { 100-grain } \\
\text { wt (g) }\end{array}$} & \multirow{2}{*}{$\begin{array}{l}\text { Grain } \\
\text { yield } \\
\text { (t/ha) }\end{array}$} & \multirow{2}{*}{$\begin{array}{l}\text { Stover } \\
\text { yield } \\
\text { (t/ha) }\end{array}$} & \multirow{2}{*}{$\begin{array}{c}\text { Harvest } \\
\text { index }(\%)\end{array}$} \\
\hline & & & Length & Diameter & & & & & \\
\hline $\mathrm{M}_{1} \mathrm{P}_{1}$ & $5.24 \mathrm{~b}$ & $5.73 \mathrm{bc}$ & 18.88 & $4.58 \mathrm{a}$ & $586.32 \mathrm{~b}$ & $31.95 \mathrm{~b}$ & $10.92 \mathrm{~b}$ & 11.71 & 48.25 \\
\hline $\mathrm{M}_{1} \mathrm{P}_{2}$ & $4.86 \mathrm{~d}$ & $5.33 \mathrm{de}$ & 18.17 & $4.10 \mathrm{c}$ & $511.16 \mathrm{e}$ & $31.11 \mathrm{~d}$ & $9.90 \mathrm{~d}$ & 10.98 & 47.42 \\
\hline $\mathrm{M}_{2} \mathrm{P}_{1}$ & $5.54 \mathrm{a}$ & $6.34 \mathrm{a}$ & 19.15 & $4.63 \mathrm{a}$ & $606.28 \mathrm{a}$ & $32.24 \mathrm{a}$ & $11.21 \mathrm{a}$ & 11.87 & 48.56 \\
\hline $\mathrm{M}_{2} \mathrm{P}_{2}$ & $5.02 \mathrm{c}$ & $5.49 \mathrm{~cd}$ & 18.63 & $4.25 \mathrm{~b}$ & $530.92 \mathrm{~d}$ & $31.26 \mathrm{~d}$ & $10.27 \mathrm{c}$ & 11.41 & 47.38 \\
\hline $\mathrm{M}_{3} \mathrm{P}_{1}$ & $4.90 \mathrm{~d}$ & $5.84 \mathrm{~b}$ & 18.65 & $4.30 \mathrm{~b}$ & $550.45 \mathrm{c}$ & $31.51 \mathrm{c}$ & $10.39 \mathrm{c}$ & 11.44 & 47.59 \\
\hline $\mathrm{M}_{3} \mathrm{P}_{2}$ & $4.29 \mathrm{e}$ & $5.11 \mathrm{e}$ & 18.10 & $4.05 \mathrm{c}$ & $503.88 \mathrm{e}$ & $30.84 \mathrm{e}$ & $9.22 \mathrm{e}$ & 10.67 & 46.34 \\
\hline $\mathrm{M}_{4} \mathrm{P} 1$ & - & - & - & - & - & - & - & - & - \\
\hline $\mathrm{M}_{4} \mathrm{P}_{2}$ & - & - & - & - & - & - & - & - & - \\
\hline$\overline{S_{x}^{-}}$ & 0.029 & 0.077 & 0.146 & 0.045 & 3.311 & 0.073 & 0.064 & 0.071 & 0.123 \\
\hline $\mathrm{CV}(\%)$ & 1.15 & 2.73 & 1.57 & 2.08 & 1.21 & 0.62 & 1.64 & 1.26 & 0.60 \\
\hline
\end{tabular}

Figures with similar letter(s) or without letter in a column do not differ significantly whereas figures with dissimilar letter(s) differ significantly at 0.05 level of probability as per DMRT. $\mathrm{M}_{1}=$ Wet condition, $\mathrm{M}_{2}=$ Field capacity, $\mathrm{M}_{3}=75 \%$ of field capacity, $\mathrm{M}_{4}=50 \%$ of field Capacity, $\mathrm{P}_{1}=$ Hydropriming, $\mathrm{P}_{2}=$ Non-priming, $\quad-=$ No germination. 


\section{Discussion}

Performance of hydroprimed seeds was tested at field condition at different levels of moisture in the experiment. The results showed that primed seed gave higher population than non-primed seeds at all soil moisture levels. Thus seed priming improves population both at optimum and sub-optimal moisture environments. Seed priming plays a vital role for increasing emergence and stand establishment. So, the plant population of maize increased with primed seed. Similar results were also found in maize by Harris et al. (2001) and Finch-Savage et al. (2004).

Hydroprimed seeds sown at field capacity exhibited the highest population whereas seeds sown in the soil having higher or lower moisture than field capacity showed lower population. Primed seeds can improve germination rate and emergence particularly under adverse seed bed conditions and at optimum condition it shows better performance. Therefore, hydroprimed seed sown at field capacity exhibited the highest population. Aboyami and Adeyini (2005) found similar results in maize. These results are also in line with the findings of Lobato et al. (2008).

Hydroprimed seeds required shorter time to complete different phenological stages, such as days to tasseling, days to silking, and days to maturity than nonprimed seeds at every level of soil moisture under the study. Seed priming reduces seedling germination time and contributes to earlier flowering and earlier maturity. So, phenological stages of maize reduced by hydroprimed seed at every level of moisture condition. Similar results were found by Harris et al. (2001) who stated that hydroprimed seeds reduced phenological stages comparing with non-primed seeds. Phenological stages of maize were lowest from hydroprimed seeds sown at field capacity whereas these were highest at lower or higher soil moisture level than field capacity.

Seed priming and soil moisture regime interacted significantly for yield performance and other plant parameters. Hydroprimed seeds gave higher number of $\mathrm{cob} / \mathrm{m}^{2}$, cob length, cob diameter, grains/cob,1000-grain weight, grain yield $(\mathrm{t} / \mathrm{ha})$, stover yield ( $\mathrm{t} / \mathrm{ha}$ ) and harvest index at different levels of moisture compared to non-primed seed. Some metabolic and physiological changes occur in the primed seeds which are helpful for faster embryo growth. Moreover, seed priming recommended for earlier DNA replication, increased RNA and protein synthesis, greater ATP availability, repair of deteriorated seed parts and reduced leakage of metabolites. Primed seeds are capable of improving germination rate and increasing stand establishment under adverse seed bed conditions, such as low temperature and moisture, metric stress and heat. As a result, grain yield and other yield contributing characters of maize also increased positively by hydroprimed seeds at every level of moisture condition. These results are at par 
with the findings of Rashid et al. (2004) and Casenave and Toseli (2007). Similar results were also found by Saif et al. (2003) and Mohammadkhani and Heidari (2008).

\section{Conclusion}

The present study revealed that hydroprimed seeds of maize showed better performance than non-primed seeds either at optimum condition or even at stressful field environment. Hydroprimed seeds sown in the field at field capacity showed the best performance of maize. So, seed priming could be used as a tool to improve yield performance of maize.

\section{References}

Aboyami, Y.A. and A.M. Adeyini. 2005. Comparative germination responses of cowpea and maize genotypes to soil moisture content. Agrosearch 7 (1\&2): 34-42.

Araus, J.I., G.A. Slafer, M.P. Reynolds and C. Toyo. 2002. Plant breeding and drought in $\mathrm{C}_{3}$ cereals, what should we breed for? Ann. Bot. 89: 925-940.

BARI (Bangladesh Agricultural Research Institute). 2004. Integrated nutrient management for sustaining soil fertility and production of Wheat-Mungbean-T. aman cropping pattern. Annual Report 2003-2004. Bangladesh Agril. Res. Inst., Gazipur 1701, Bangladesh, Pp. 333-335.

BARI (Bangladesh Agricultural Research Institute). 2006. Krishi Projukti Hatboi (in Bengali). Bangladesh. Agril. Res. Inst., Gazipur 1701, Bangladesh, P. 45.

BBS. 2010. Statistical Year Book of Bangladesh. Bangladesh Bureau of Statistics, Ministry of Planning, Government of the People's Republic of Bangladesh, Pp.37-49.

Casenave, E.C. and M.E. Toselli. 2007. Hydropriming as a pre-treatment for cotton germination under thermal and water stress conditions. Seed Sci. Technol. 35(1): $88-98$.

Finch-Savage, W.E., K.C. Dent and L.J. Clark. 2004. Soak conditions and temperature following sowing influence the response of maize (Zea mays L.) seeds to on-farm priming (pre-sowing seed soak). Field Crops Res. 90(2/3): 361-374.

Gomez K.A. and A.A. Gomez. 1984. Statistical Procedures for Agriculture Research. Intl. Rice. Res. Inst., Philippines, Pp.187-411.

Hall, A.J., D.J. Conner and D.M. Whitfield. 1990. Root respiration during grain filling in sunflower: the effect of water stress. Plant Soil 121: 57-66.

Harris, D., A. Joshi, P.A. Khan, P. Gothakar, and P.S. Sodhi. 1999. On-farm seed priming in semi-arid agriculture: Development and evaluation in corn, rice, and chickpea in India using participatory methods. Exp. Agric. 35:15-29.

Harris, D., A.K. Pathan, P. Gothkar, A. Joshi, W. Chivasa and P. Nyamudeza. 2001. Onfarm seed priming: using participatory methods to revive and refine a key technology. Agril. Systems. 69:151-164. 
Heydecker, W. J., J. Higgins and K. Gulliver. 1973. Accelerated germination by osmotic seed treatment. Nature 246: 42-46.

Hossain, A. and M. Shahjahan. 2007. Grain quality evaluation of the major varieties or cultivar of maize. Research report of the year 2006-07. Post harvest Technology Division, BARI, Joydebpur, Gazipur, Pp. 1-6.

Jun Chen and Dai Junying. 1996. Effect of drought on photosynthesis and grain yield of corn hybrids with different drought tolerance. Acta Agron. Sin. 22 (6): 757-762.

Lobato, A.K.S., C.F.Oliveira, R.C.L. Costa, B.G.S. Filho, F.K.S. Silva, F.J.R. Cruz, A.C.S. Abboud and H.D. Laughinghouse. 2008. Germination of sorghum under the influences of water restriction and temperature. Agril. J. 3(3): 220-224.

McDonald, M.B. 2000. Seed Technology and Its Biological Basis. Sheffield Academic Press Ltd., Sheffield, UK, Pp. 287-325.

Michael, A.M. 1978. Irrigation theory and practice. Vikash Publishing House Pvt. Ltd., New Delhi, P.542.

Misra, R.D. and M. Ahmed.1993. Determination of field capacity (Field method). Manual of Irrigation Agronomy. Oxford \& IBH Publishing Co. Pvt. Ltd. New Delhi, Calcutta, Pp. 48-50

Mohammadkhani, N. and R. Heidari. 2008. Water sress induced by polyethylene glycol 6000 and sodium chloride in two maize cultivars. Pak. J. Biol. Sci. 11(1):92-97.

Rahman, M.U., S. Gul and I. Ahmad, 2004. Effects of water stress on growth and photosynthetic pigments of corn (Zea mayz L.) cultivars. Int. J. Agric. Biol. 4: 652-655

Rashid, A., D. Harris, P.A. Hollington and M. Rafiq. 2004. Improving the yield of mungbean (Vigna radiata L.) in the North West Frontier Province of Pakistan using on-farm seed priming. Centre for Arid Zone Studies, University of Wales, Wales, UK. 40: $233-244$.

Saif, U., M. Maqsood, M. Farooq, S. Hussain and A. Habib. 2003. Effect of planting patterns and different irrigation levels on yield and yield component of maize (zea mays 1.). Int. J. Agric. Biol. 5(1): 64-66.

Singh, B.G. 1995. Effect of hydration dehydration seed treatments on vigour and yield of sunflower. Indian J. Plant. Physiol. 38: 66-68.

Townend, J., P.W. Mtakwa, C.E. Mullins and I.P. Simmonds. 1996. Soil physical factors limiting establishment of sorghum and cowpea in two contrasting soil types in the semi-arid tropics. Soil Till. Res. 40: 89-106. 